\title{
Theory and practice in second language syllabus design
}

\section{Johann L. van der Walt}

The syllabus is an essential factor in the achievement of communicative competence in second language teaching. Various proposals for syllabus design have been made, ranging from product to process syllabuses. Their theoretical bases and the practical constraints which influence them are discussed. The product syllabus is a formal statement of the end product, and has been criticized mainly because it cannot account for communicative competence in the syllabus design itself and because it may encourage a step-by-step teaching procedure. The process syllabus attempts to address learning procedures and is concerned with learning experiences and the negotiation of meaning. This approach is also not without its critics. But practical factors such as administrative requirements, teacher capacity and learner differences constrain the syllabus design. It is concluded that a process syllabus which specifies the classroom activities in much more detail than has been the case so far, and which contains product elements to accommodate some of the constraints, is likely to realize the aim of communicative competence.

Die sillabus is ' $n$ belangrike element in die bereiking van kommunikatiewe vaardigheid in tweedetaalonderrig. Verskeie voorstelle vir die ontwerp van sillabusse is reeds gedoen, en strek vanaf produk- tot prosessillabusse. Die teoretiese basis van hierdie sillabusse sowel as die praktiese beperkinge wat hulle beïnvloed, word bespreek. Die produksillabus is ' $n$ formele verklaring van die eindproduk, en word veral gekritiseer omdat dit nie rekenskap kan gee van kommunikatiewe vaardigheid in die sillabusontwerp selfnie, enomdat dit aanleiding kan gee tot ' $n$ stap-vir-stap onderrigbenadering. Die prosessillabus poog om die leerproses in ag te neem en leerervarings te spesifiseer, en beklemtoon die onderhandeling van betekenis. Hierdie benadering is ook nie sonder sy kritici nie. Maar praktiese faktore soos administratiewe vereistes, onderwyserbevoegdheid en verskille tussen leerders, het ' $n$ beperkende invloed op die ontwerp van die sillabus. Die gevolgtrekking word gemaak dat 'n prosessillabus wat die klaskameraktiwiteite in baie meer detail spesifiseer as wat tot nou toe die geval was, en wat produkelemente bevat om sommige van die praktiese beperkings te akkommodeer, die doelstelling van kommunikatiese vaardigheid waarskynlik die beste kan realiseer.

\section{Introduction}

The ultimate purpose of most general courses in second languages is to make the learner proficient in the language. In centrally controlled school systems, the syllabus or subject 
curriculum is an important instrument in the achievement of this goal, which is generally expressed in syllabuses as the aim of communicative competence. Various proposals for the achievement of communicative competence have been suggested, leading to an array of proposals for syllabus design, especially as far as the subject matter of second language teaching is concerned.

The aim of this article is to investigate some of the issues the syllabus designer faces when drawing up a second language syllabus. It will focus on the theoretical bases of approaches to syllabus design and try to determine to what extent a syllabus can be theoretically pure, as well as on the practical constraints which play a role in the design of such a syllabus.

\section{The second language syllabus}

Most definitions of a syllabus in language teaching refer to the linguistic content and the principles that underlie that content (see Wilkins 1976b: 5, for example). Under the influence of curriculum studies (e.g. Taba 1962; Wheeler 1967) attention has shifted to the specification of needs and communicative objectives as additional components in second language syllabus design (Shaw 1977: 219). The discussion has recently centred around the question of whether methodology forms part of the syllabus or not (see Stern 1984:7). Most current syllabuses seem to exclude methodology from the syllabus specification, and include at the utmost only guidelines for the implementation of the syllabus.

\section{Approaches to syllabus design}

A theory of language and language learning is implicit in the practice of language teaching (Stern 1983: 23), and it reveals itself in, amongst other things, the syllabus. A syllabus will therefore reflect a particular view of language and language learning. Amongst the various proposals for syllabus design, two basic approaches can be distinguished, namely a productbased and a process-based one. These are prototypical syllabuses of which there are many versions. Each implies a different concept of language and language learning. Both are briefly discussed in the following paragraphs.

\subsection{Product-based syllabuses}

Product-based syllabuses provide a specification of what has to be mastered by the learner. They are thus primarily concerned with ends. Such syllabuses reflect categories determined by analysts of language, and typically consist of inventories of items to be mastered by the learner, derived from a specific view of the subject matter.

We can distinguish between linguistic and interactional categories in this type of syllabus specification. Of the former, linguistic structures have been the most popular in syllabus design, but this category can also include a semantic category such as notions (when it means semantico-grammatical, as proposed by Wilkins 1976a). A linguistic organisation gives priority to the structure of language, and Brumfit (1984: 78) argues that it presumes that we 
first learn the language system (either inductively or deductively) and then use it freely for communication. The interactional category identifies situations in which language occurs and main types of language purpose such as functions, and this organisation presumes that language learning means learning to discourse, to interact and to communicate, either inductively or deductively. It has not always proved easy to integrate both these categories in syllabus design. The product syllabus represents language knowledge and capability as a propositional plan (Breen 1987: 85) and formally states what is to be achieved through teaching and learning.

\subsection{Criticism of the product-based approach}

Product-based syllabuses have been criticized on various grounds. Structural syllabuses came under increasing criticism in the 1970s because they did not conform to the changing views of language that emerged during this time (Wilkins 1976a). A view of language as a set of structures was regarded as too confining, as it ignored the communicative purposes for which language is used. The structural syllabus has also been criticized because of the difficulties involved in the selection and grading of structures (see Wilkins 1976a:7-13). The functional-notional syllabus was initially suggested by Wilkins (1976a) as an alternative to the structural syllabus, but it has in turn been criticized because it consists of a set of isolates to be mastered and depends on the ability of the syllabus designer to specify the needs of the leamer (see Brumfit 1981). It has also been criticized for its attempt to account for communicative competence within the actual design of the syllabus. It is very difficult to do so, because, as Widdowson (1978: 248 ) points out, communicative competence is not "the compilation of items in memory, but a set of strategies or creative procedures for realizing the value of linguistic elements in contexts of use, an ability to make sense as a participant in discourse, whether spoken or written, by the skilful deployment of shared knowledge of code resources and rules of language use". The functional-notional syllabus therefore deals with the components of discourse, and not with discourse itself. It departs very little from the structural syllabus in that both of them derive from analyses made by the linguist and as such do not centre on the learner.

The evidence from second language acquisition (SLA) research (see Lightbown 1986) points to the fact that the acquisition of a language is not a linear or cumulative process, but rather an organic one (Lightbown 1986: 177; Corder 1986:187). Acquisition is not the obverse of teaching, and the learner's built-in syllabus may not coincide with the syllabus used in class. It therefore serves little or no purpose to follow a predetermined sequence of language items. Language is a complex hierarchical system whose components interact in non-linear ways. (Lightbown 1986: 178). The natural order hypothesis (Krashen 1985), prematurely regarded by some as the answer to content selection problems, has merely reached the stage of a potentially testable hypothesis and cannot be used as the basis for content selection (Lightbown 1986; van der Walt 1988). The argument that adults and adolescents can "acquire" the language (in Krashen's sense of the word) has been used by critics of the product syllabus to discourage the selection of grammatical items and basing teaching on a list of these items. 
As far as teaching methodology is concerned, Lightbown (1986: 181) says: "The method of proceeding step-by-step, from one grammatical building block to another - each block carefully and precisely placed, once and for all - simply finds no support in the acquisition research". A product-based specification of items, be they structures or functions, is likely to lead to this step-by-step method of teaching, but it may not result in an acceptable level of communicative competence in the learner (see Johnson 19982a:1, who speaks of the phenomenon of the "structurally competent but communicatively incompetent student").

These and other criticisms have led to a reconsideration of the product-based specification, and have given rise to proposals for the second type of syllabus, the process-oriented one.

\subsection{Process-based syllabuses}

Process-based approaches are based on a view of the curriculum represented by, amongst others, Stenhouse (1975). They attempt to address the question of how language is learned in the syllabus design itself. Their point of departure is the learning processes through which knowledge and skills are acquired (Nunan 1988: 40). In this type of syllabus we have an integration of content and classroom procedures or, as Candlin (1984: 33) puts it, "as much a concern with learning experiences as with the subject-matter of those experiences".

The basic premise in this approach is that the human being is programmed to acquire a language, be it a first or a second one, and that this process occurs naturally through a focus on meaning. Krashen (e.g. 1982) has been a very vocal advocate of the view that focusing on form is unlikely to lead to improvement in spontaneous communicative ability, and he is not in favour of a predetermined language syllabus. Teaching must create the conditions for acquisition to take place, and must focus learners on meaning and not form. The underlying ability to develop in language learning is the ability to negotiate meaning - this is seen as the catalyst for the learning and refinement of language knowledge itself. Negotiation implies that the learner's job is to make sense in the language (Sinn entwerfen); to arrive, through negotiation, at mutually agreed meanings and behaviour. The best way of achieving this in the classroom is by means of activities and tasks, as these focus on meaning and stimulate the learning processes through which language is acquired. Problem-solving tasks, especially, serve to engage the learner's reasoning capacities (see Prabhu 1987: 47), thus focusing him on the non-linguistic outcomes of the tasks rather than on the accompanying and facilitating language (Candlin 1984: 42). No selection and grading of language items are required.

There are two major versions of this approach, namely that of Prabhu (1987) and that of Candlin $(1984 ; 1987)$ and Breen (1987). Prabhu represents communicative competence as a range of tasks to be undertaken and achieved, and regards the learning process as appropriate content for language learning. Candlin and Breen regard any preplanned syllabus as redundant from the moment of implementation as it is always reinterpreted by both teacher and learner. The syllabus must therefore address teacher and learner capacities to select and sequence subject matter for language learning which they jointly perceive as most valuable to them (Breen 1987: 166). A syllabus should consist of a bank of alternative activities and 
tasks, each categorized in terms of their own objectives, content, suggested procedure, and suggested ways of evaluating outcomes (Breen 1987: 167).

\subsection{Criticism of the process-based approach}

Process syllabuses at first appear to be theoretically sound: they are based not only on SLA studies but also on well-established educational practice (for example, the Discovery Method and the Activity Approach). A problem, however, is that our knowledge of second language acquisition remains limited by the fact that only certain domains of syntax and morphology have been studied in detail (see Ellis 1985:5). Krashen's theory is based on the results of the study of a limited number of morphemes and has been criticized by a number of researchers for its weak empirical basis (e.g. McLaughlin 1987; Gregg 1984). Another problem is that research based on naturalistic second language development is unadvisedly applied to language teaching in the classroom (see Ellis 1984: 190). The "organic" model of acquisition remains an essentially simple account of a very complex process. Somerville-Ryan (1987: 93) argues that it is difficult to prove or disprove this theory. Krashen (1982) is opposed to formal instruction as he believes that there is no interface between "learning" and "acquisition"; but "learning" can take many forms, and some researchers argue that it can contribute to (and become) "acquisition"(e.g. Sharwood Smith 1981; Rutherford 1987). Product-based approaches do not focus exclusively on form, as is often implied - meaning must of necessity be attended to. Greenwood (1985: 271) points out that many activities in Prabhu's methodology are similar to those found in a course based on a structural or notional syllabus. The tasks give rise to conceptual components which resemble Wilkins' semantico-grammatical categories (see Johnson 1982b: 141).

Somerville-Ryan (1987: 93) points out that a process syllabus may have the practical effect of shifting the focus of accountability from the "approach" to the pupil. Another problem is that there is as yet no agreement on what constitutes a task and how they should be classified and graded (van der Walt 1988:107; Nunan 1988:45). Any task-based approach should make provision for sufficient comprehensible input, and this does not always appear to be the case. It is also not certain that certain task-types will always meet the prerequisite of making genuine demands on the learner's pragmatic skills (see Huckin 1980: 217).

\subsection{Product or process approach?}

The syllabus designer is faced with a difficult decision when he has to decide on a basic approach, because ideally such an approach should be theoretically sound. It is clear, however, that both prototypical syllabuses discussed above can be criticized on various grounds and that no final answers as regards content selection can be given. A major concern is the aim of the course. The aim of communicative competence in a general school course implies that the learner should become proficient in the use of the language, i.e. the overriding target is competence in unplanned discourse (Ellis 1984:168). The syllabus must therefore encourage the creation of an optimal learning environment in which unplanned discourse can be produced. Two factors need to be considered by the syllabus designer. First, the effect of 
a syllabus must be empirically demonstrated, and the designer will have to examine such evidence. Second, the practical constraints which may have an influence on the syllabus design need to be taken into account.

\section{Empirical evidence}

Of interest here is the practical demonstration of the process approach. With the exception of Prabhu's syllabus there has not been any concerted effort to evaluate a task-based approach in actual operation, although there is a growing body of research into the effects of procedure on language learning in tutored settings (White 1988: 110). Prabhu's syllabus-in-action has been evaluated by Beretta and Davies (1985: 121-7). While admitting certain limitations in the evaluation procedure, such as the impossibility of full experimental control and the potential for bias in test construction, their conclusions are, on the whole, positive, and they provide tentative support for the claim that "grammar construction can take place through a focus on meaning alone". Breen and Candlin's syllabus has not been empirically investigated. The results of other, related syllabuses, such as Krashen and Terrell's (1983) Natural Approach, in which activities which promote subconscious acquisition rather than conscious learning are central, have also proved to be positive (see Terrell 1982: 121-31).

Studies of language teaching methods are notoriously difficult because of the number of variables to be controlled (for a review, see Freedman 1971; Allwright 1983) and it is difficult to prove beyond any doubt the superiority of one syllabus or method over another.

The syllabus, however, is a practical instrument, and there are certain factors which will have a very strong influence on its design. These are now briefly considered.

\section{Practical constraints in syllabus design}

A syllabus is the culmination-point of a complex set of factors in practice. By its very existence it implies certain ideological, social and political presuppositions. It serves as an administrative instrument which provides a statement of work to be done, and what has to be achieved through teaching and leaming. It provides an administrative base which specifies responsibility, maintains continuity and makes available a common statement of terms of reference (Brumfit 1984: 76). It is open to public scrutiny and is accountable ultimately to society at large. It serves as a basis for evaluation to determine whether teaching has fulfilled the expectations of the community. A syllabus can only be a device for teaching, which can be publicly influenced, if not controlled, but it cannot define learning, which is an immensely complex and varied private operation (Brumfit 1984: 76). It is further limited by time, physical space and the availability of equipment. It is a practical document, and if it functions ineffectively it is a bad syllabus. All these factors impose severe restraints on its theoretical purity.

The syllabus designer must also take into consideration teacher capacity. Within a process 
approach, the teacher is more than an instructor; he is a facilitator and manager of learning. Candlin (1985: 110) regards him as informant, resource, guide and co-ordinator, syllabus designer, classroom researcher, and sharer of responsibility. The teacher's role is therefore a very complex one. He remains, however, accountable for his teaching. He requires from the syllabus that it should provide him with a sense of direction, and it can be argued that teaching will be most effective when the syllabus follows a well-worked out plan which directs and organizes what the teacher does (Ellis 1985: 243). The teacher must find this plan logical and acceptable. His implementation of the syllabus will also reflect his own views on language and language learning, which may not necessarily coincide with that of the syllabus. His style of teaching will also be a major determining factor. The teacher therefore also acts as a major constraint on the syllabus.

Syllabuses are written with learners in mind, but because of the many individual differences among them, this is no easy matter. Aptitude, motivation and personality are factors which influence success in language learning (Ellis 1985: 123). Learning style is another complicating consideration. Proponents of process syllabuses argue that learners do not need formal instruction in the second language, yet there is evidence that some learners prefer such instruction (see Pickett, 1978) and that it has a positive effect on the rate and success of second language learning (see van der Walt 1988: 109 for a discussion).

It is clear from this discussion that there are many practical variables which influence syllabus design. The situational constraints of actual teaching situations within which a syllabus has to be converted into teaching and learning practice cannot be negated by the syllabus designer. These constraints to some extent encourage the adoption of a product-based syllabus, as it conforms to a widespread conception among teachers and learners of what language teaching and learning entail, as well as to the expectations of parents and society at large. It also provides the teacher with security and direction, accommodates a widespread teaching style, and can easily make provision for learners with a preference for formal instruction. It can also enable both teacher and learner to come to terms with the constraint of time, as the time available in a school is usually very limited, and attention to product elements can be a short cut to mastery of the language.

\section{Conclusion}

A syllabus in second language teaching can only partly be justified on theoretical grounds. There is as yet no theoretically pure syllabus, as both product and process syllabuses can be criticized on theoretical as well as practical grounds. A theory-driven syllabus, however, remains an essential requirement, as language teaching cannot take place without a conceptual framework which gives effective direction to the enterprise. The product-process distinction is therefore best regarded as a continuum on which any syllabus can be placed, as it is likely to contain both product and process elements in practice.

Some writers make out a case, based on the available evidence, for a theory-driven syllabus to be located on the process end of the continuum. White (1988: 110), for example, says there 
is considerable doubt regarding the traditional justifications for product syllabuses, and suggests that methodology rather than syllabus may hold the key to successful language teaching and leaming. The process syllabus encourages the creation of an optimal leaming environment, in which unplanned discourse features prominently. It is also argued that the process syllabus ensures that communication and meaningful interaction take their rightful place in the teaching programme. A syllabus must, however, make provision for product elements, not only as a result of theoretical considerations, but also because of the various constraints on the design and implementation of the syllabus. The resultant syllabus would therefore be a hybrid one.

A major implication of this approach is a rethink of current second language syllabus design, as it implies that a very important place should be allocated to methodology in the actual design itself. This can no longer be left to the teacher to decide on for himself. The learning experiences required need to be specified in much more detail than is presently the case in most syllabuses, as they guide and influence the process of language leaming. What happens in the classroom is much more important than the content selected for teaching. Such a specification would enable language learning to become truly communicative - utilizing communicative tasks and activities - and lead to successful teaching in state-controlled school systems.

\section{Bibliography}

ALLWRIGHT, R.L. 1983. Classroom-centred research on language teaching and learning: a brief historical review. TESOL Quarterly 17(2): 191-204.

BERETTA, A. and A. Davies. 1985. Evaluation of Bangalore project. ELT Journal 39 (2): 121-127.

BREEN, M.P. 1987. Contemporary paradigms in syllabus design. Language Teaching 20(2 and 3): 81-92; 157-174.

BRUMFIT, C.J. 1981. Problems and principles in English teaching. Oxford: Pergamon Press.

BRUMFIT, C J. 1984. Function and structure of a state school syllabus for learners of second or foreign languages with heterogeneous needs. In: Brumfit, C.J. (Ed.). General English syllabus design. ELT Documents 118. Oxford: Pergamon Press/The British Council.

CANDLIN, C.N. 1984. Syllabus design as a critical process. In: Brumfit, C.J. (Ed.). General English syllabus design. Oxford: Pergamon Press/The British Council.

CANDLIN, C.N. 1985. Teacher-centred training: costing the process. In: Quirk, R. and Widdowson, H.G. (Eds.). English and the world: teaching and learning the language and literatures. Cambridge: Cambridge University Press. 
CANDLIN, C.N. 1987. Towards task-based language learning. In: Candlin, C.N. and Murphy, D.F. (Eds.). Language learning tasks. London: Prentice-Hall.

CORDER, S.P. 1986. Talking shop. ELT Journal 40(3): 185-190.

ELLIS, R. 1984. Classroom second language development. Oxford: Pergamon Press.

ELLIS, R. 1985. Understanding second language acquisition. Oxford: Oxford University Press.

FREEDMAN, ELAINE S. 1971. The road to Pennsylvania - where next in language teaching experimentation? Audio-Visual Language Journal 9(1): 33-38.

GREENWOOD, J. 1985. Bangalore revisited: a reluctant complaint. ELT Journal 39(4): 268-273.

GREGG, K.R. 1984. Krashen's Monitor and Occam's razor. Applied Linguistics 5(2): 79100.

HUCKIN, T.N. 1980. Review of H.G. Widdowson: Teaching language as communication, Language Learning 30(1): 209-227.

JOHNSON, K. 1982a. Some background, some key terms and some definitions. In: Johnson, K. and Morrow, K. (Eds.). Communication in the classroom. Harlow: Longman.

JOHNSON, K. 1982b.Communicative syllabus design and methodology. Oxford: Pergamon Press.

KRASHEN, S.D. 1982. Principles and practice in second language acquisition. Oxford: Pergamon Press.

KRASHEN, S.D. 1985. The input hypothesis. London: Longman.

KRASHEN, S.D. and T.D. Terrell 1983. The natural approach. Oxford: Pergamon Press/ Alemany Press.

LIGHTBOWN, PATSY M. 1986. Great expectations: second-language acquisition research and classroom teaching. Applied Linguistics 6(2): 173-189.

McLAUGHLIN, B. 1987. Theories of second-language learning. London: Edward Arnold.

NINAN, D. 1988. Syllabus design. Oxford: Oxford University Press.

PICKETT,G.D. 1978. The foreign language teaching process. London: The British Council. 
PRABHU, N.S. 1987. Second language pedagogy. Oxford: Oxford University Press.

RUTHERFORD, W.E. 1987. Second language grammar: learning and teaching. London: Longman.

SHARWOOD SMITH, M. 1981. Consciousness-raising and the second language learner, Applied Linguistics 2(2): 159-169.

SHAW, A.M. 1977. Foreign-language syllabus development: some recent approaches. Language teaching and linguistics: abstracts 10(4): 217-233.

SOMERVILLE-RYAN, R.B. 1987. Taking slow-learners to task. In: Candlin, C.N. and Murphy, D.F.(Eds.). Language learning tasks. London: Prentice-Hall.

STENHOUSE, L. 1975. An introduction to curriculum research and development. London: Heinemann.

STERN, H.H. 1983. Fundamental concepts of language teaching. Oxford: Oxford University Press.

STERN, H.H. 1984. Review and discussion. In: Brumfit, C.J.(Ed.). General English syllabus design. Oxford: Pergamon Press/The British Council.

TABA, HILDA. 1962. Curriculum development: theory and practice. New York: Harcourt, Brace and World.

TERRELL, T.D. 1982. The natural approach to language teaching: an update. Modern Language Journal 66(2): 121-32.

VAN DER WALT, JOHANN L. 1988. Interlanguage studies and formal instruction in second language teaching and acquisition. S.A. Journal of Linguistics 6(3): 10114.

WHEELER, D.K. Curriculum process. London: University of London Press.

WHITE, R.V. 1988. The ELT curriculum: design, innovation and management. Oxford: Basil Blackwell.

WIDDOWSON, H.G. 1978. Explorations in applied linguistics. Oxford: Oxford University Press.

WILKINS, D.A. 1976a. Notional syllabuses. London: Oxford University Press.

WILKINS, D.A. 1976b. Notional syllabuses: theory into practice. Bulletin CILA 24: 5-17. 